\title{
GEODIVERSITY MAP OF THE TATRA NATIONAL PARK FOR GEOTOURISM
}

\author{
ZBIGNIEW ZWOLIŃSKI \\ Adam Mickiewicz University, Institute of Geoecology and Geoinformation, Poznań, Poland \\ JAKUB STACHOWIAK \\ Systherm Info, Poznań, Poland
}

Manuscript received: January 12, 2011

Revised version: February 19, 2012

\begin{abstract}
Zwoliński, Zв., SтAсноWiak, J., 2012. Geodiversity map of the Tatra National Park for geotourism. Quaestiones Geographicae 31(1), Bogucki Wydawnictwo Naukowe, Poznań 2012, pp. 99-107. 5 Figs., 1 Tab. DOI 10.2478/ v10117-012-0012-x, ISSN 0137-477X.
\end{abstract}

AвSTRACT. The paper indicates the relations between geodiversity and geotourism in the Tatra National Park. Geodiversity of the Tatra Mountains is visualized by its geodiversity map, whereas geotouristic attractions are measured by touristic attractions along touristic trails on geodiversity map. Areas of the highest geodiversity cover merely $8.2 \%$ of the Tatar National Park area. These are mainly areas close to the Tatra Mountains' main ridge. It is so due to geology, landform energy, slopes, landform fragmentation and geoecological belts. Most of the analyzed thematic layers categorizes ridges as more geodiversed than valley areas. The trails situated in the valley bottoms usually cross by areas of low geodiversity, however, from geotouristic point of view, it should be noted that slopes and ridges circumvolving the valley can be marked by high geodiversity. The mountain slopes and ridges are within tourist's sight, what increases trail's geotouristic attractiveness. Amongst many geotouristically interesting parts of the Tatra Mountains Dolina Pięciu Stawów valley appears to be the most appealing with its high quantity and high variety of post-glacial forms on valley's bottom as well as on its slopes.

KEY WORDS: geodiversity, geotourism, map algebra, WLC, Tatra Mountains

Zbigniew Zwolinski, Institute of Geoecology and Geoinformation, Adam Mickiewicz University, Dzięgielowa 27, Poznań, Poland, e-mail:zbzw@amu.edu.pl

\section{Introduction}

Geographical sciences, in respect of their unique universality in as far as the subject of research and scientific methods, easily adapt concepts, scientific approaches, terminology and scientific methods from other natural sciences. It can be concluded that geodiversity, modeled on biodiversity (biological diversity), is such an adapted term, which was first introduced on Rio de Janeiro Earth Summit, 1992. Geodiversity apply to the entire geographic environment, yet it is clearly connected with abiotic sphere. The most popular definition of geodiversity is provided by Gray (2004, p. 8), meaning the natural range (diversity) of geological (rocks, minerals, fossils), geomorphological (landform, processes) and soil features. It includes their assemblages, relationships, proper- 
ties, interpretations and systems. At the same time Zwolinski (2004a) concludes that the term geodiversity is commonly used in two meanings. The first one refers to the whole range (i.e. diversity) of geological, geomorphological and soil phenomena, and treats geodiversity as an objective, value-neutral property of a real geosystem. The other usage conveys the idea that geodiversity refers specifically to particular geosystems that are in themselves complex (diverse). In all geodiversity definitions that can be found in the literature it is stated in an unambiguous way that it refers to natural environment features. Gray (2008) thinks that the idea of geodiversity deserves to be a paradigm. Mizgajski (2001) considers that the concept of geodiversity is closely related to landscape structure study in the field of complex physical geography. Kostrzewski $(1998,2000)$ attributes equally important role to landform geodiversity in geomorphology.

Geotourism, on the other hand, can be defined as a form of cultural-environmental tourism that can develop in areas with important geological monoliths, which are exploited to attract visitors with special interests (Asrat et al. 2008). More elaborate definition is provided by Hose (2008): the provision of interpretative facilities and services to promote the value and societal benefit of geological and geomorphological sites and their materials, and to ensure their conservation, for the use of students, tourists and other casual recreationalists.

When one compares two definitions - geodiversity and geotourism - analogies inevitably appear: both concepts concern geographical environment in abiotic sphere and accentuate the role of geological and geomorphological features. The terms biodiversity and ecotourism appear to be counterpoint to the above mentioned terms, but they should not exist in opposition to geodiversity and geotourism. The concept of biodiversity, derived from the Convention on Biological Diversity, was created by politicians, decision-makers and environmental activists, while the concept of geodiversity arose in scientific workgroups, mainly those of protected areas in Australia (Sharples 1993 after Gray 2008). The ideas of geotourism and ecotourism underwent similar creative process. The former concept was formulated by the geologists, while the latter was established by Quebec Declaration on Ecotour- ism in 2002. Undoubtedly, the consideration for of natural environment protection is the common feature of all these ideas.

The aim of this paper is to indicate connections between geodiversity and geotourism. Geodiversity's range of any given area can be visualized by geodiversity map, whereas geodiversities attractions can be measured by means of touristic routes on geodiversity maps. The attempt to distinguish connections between geodiversity and geotourism was undertaken in the Tatra National Park (TPN), the only high-mountain area of alpine landscape in Poland. Such a scientific approach which combines geomorphological maps, touristic infrastructure and geodiversity together with geotourism into geoheritage is repeatedly used by many authors such as Zwoliński (2004b), Sapp et al. (2009), Joyce (2010), Castaldini (2012), Cayla et al. (2012), Reynard et al. (2012), Rodrigues \& Fonseca (2012).

\section{Study area (TPN 2012)}

The Tatra National Park was founded in 1954 to protect one of the most precious treasures of European nature - the highest part of the Carpathians, named the Tatras. The Park has a surface area of $212 \mathrm{~km}^{2}$ and covers approx. $20 \%$ of the whole surface of this mountain range. The Tatras are considered to be a unique place because of many reasons. The main of them however is very simple: although they are relatively small (their total area $-785 \mathrm{~km}^{2}$ is comparable to the one of a middle-size alpine valley and the highest point within Polish borders - Rysy is only 2,499 m a.s.1.), due to their relief and specific flora and fauna, they can be regarded as the high mountains in an alpine landscape. The Tatras (within the TPN borders) are divided into two main parts: Western Tatras and High Tatras. The southern part of Tatras is built of metamorphic rocks (mainly schists), the second - of granitoids. These rocks constitute the Paleozoic crystalline basement. Northern zones of both High and Western Tatras are composed of sedimentary rocks, such as limestones, sandstones, dolomites and shales, which were folded and displaced during alpine mountain building period. The relief of the Tatra Mountains was formed by Pleistocene mountain 
glaciers, therefore nowadays can be observed landforms such as cirques, u-shaped valleys, hanging valleys etc. The most picturesque proof of glaciers' presence in the Tatras are numerous lakes and waterfalls. Another interesting relief type occurs within sedimentary rocks where can be find many caves, potholes and other karst landforms.

Climate of the Tatras is typical for mountainous regions. Its components such as temperature, atmospheric humidity, precipitation, snowfall, length of vegetation season etc. are significantly related to the altitude. Another important characteristic of Tatra climate is relatively frequent occurrence of local foehn wind, called halny. Vertical climate changes determine the distribution of vegetation belts. In the Tatras there are five of them: beech forests (up to 1,250 $\mathrm{m}$ a.s.l., nowadays, due to artificial changes, they are almost totally replaced by spruces), spruce forests (1,250-1,550 $\mathrm{m}$ a.s.l.), dwarf mountainpine belt (1,550-1,800 $\mathrm{m}$ a.s.l.), alpine grasslands (1,800-2,300 $\mathrm{m}$ a.s.l.) and subnival belt - bare rocks (above 2,300 $\mathrm{m}$ a.s.1.). Flora of the TPN is highly diverse. It contains about 1,000 species of vascular plants, among them endemic ones, such as Poa granitica, Poa nobilis, Cochlearia Tatrae. In the Tatras we can also find some relict species mainly from the ice age like Dryas octopetala, Salix reticulata, Salix herbacea. Fauna of the TPN is also reach and diversed. Tatra forests are home for animals such as red deer (Cervus elaphus), roe deer (Capredus capredus), lynxes (Lynx lynx), otters (Lutra lutra), wolves (Canis lupus), brown bear (Ursus arctos) and many others. Tatran chamois (Rupicapra rupicapra), the marmot (Marmota marmota), the Alpine accentor (Prunella collaris) the wall creeper (Tichodroma muraria) and the golden eagle (Aquila chrysaetos) are the examples of species inhabiting areas situated above the timber line.

\section{Geodiversity map of the Tatra Mountains}

Geodiversity maps can be derived using many different procedures and according to various criteria. In Poland such procedures were presented by: Kot $(2006,2009)$, Kot \& Leśniak (2006),
Zwoliński (2007, 2008, 2009, 2010), Kot \& Szmidt (2010), Chybiorz (2011). Amongst proposed approaches to geodiversity maps derivation those suggested by Serrano\&Ruiz-Flaño (2007), Jačková \& Romportl (2008) and Serrano et al. (2009) are worth thorough consideration. In order to design a geodiversity map of the Polish part of the Tatra Mountains there were eleven elements of abiotic sphere chosen (GeoPortal Tatry, 2012):

\section{Geological elements:}

Geology: very low geodiversity - slates, shales, marls and fluvial deposits, low geodiversity - peats, tills, mylonites, dolomite breccias, moraine covers and boulder covers, medium geodiversity - radiolarities, dolomite and limestone deposists, conglomerates and quartz veins, high geodiversity - dolomites, limestones, quartzites and sandstones (with limestone deposits), very high geodiversity - gneisses, granites i granodiorites.

Caves: very low geodiversity - length below $1 \mathrm{~km}$, altitude 915-1,220 m a.s.l., low geodiversity - length 1-5 km, altitude 1,220-1,380 m a.s.l., medium geodiversity - length $5-10 \mathrm{~km}$, altitude 1,380-1,590 m a.s.l., high geodiversity - length $10-20 \mathrm{~km}$, altitude 1,590-1,760 m a.s.l., very high geodiversity - length over $20 \mathrm{~km}$, altitude 1,7602,250 m a.s.1.

\section{Geomorphological elements:}

Landform fragmentation: very low geodiversity - TPI: plains, low geodiversity - TPI: open slopes, upper slopes, messas, medium geodiversity TPI: - midslope ridges, small hills in plains, local ridges, midslope drainages, shallow valleys, high geodiversity - TPI: canyons, deeply incised streams (V-shaped), upland drainages, headwaters, very high geodiversity - TPI: mountain tops, high ridges, postglacial valleys (U-shaped).

\section{Geomorphometric elements:}

Landform energy (local elevation): very low geodiversity $-0-7 \mathrm{~m}$, low geodiversity $-8-16 \mathrm{~m}$, medium geodiversity - 17-28 $\mathrm{m}$, high geodiversity - 29-50 m, very high geodiversity - >50 m.

Slopes: very low geodiversity - $0-13 \%$, low geodiversity - 13-24\%, medium geodiversity $24-34 \%$, high geodiversity $-34-46 \%$, very high geodiversity - over $46 \%$. 


\section{Hydrographical elements:}

Lakes: very low geodiversity - depth below $2.5 \mathrm{~m}$, altitude below 1,089 $\mathrm{m}$ a.s.l., area below 0.84 ha, low geodiversity - depth 2.5-5.9 m, altitude 1,089-1,393 m a.s.l., area $0.8-3.8$ ha, medium geodiversity - depth 5.9-15.1 m, altitude 1,3931,694 m a.s.l., area 3.8-12.7 ha, high geodiversity - depth 15.1-34.6 m, altitude 1,694-1,790 m a.s.1., area 12,7-20.6 ha, very high geodiversity - depth over $34.6 \mathrm{~m}$, altitude over 1,790 $\mathrm{m}$ a.s.l., area over 20.6 ha.

Springs: very low geodiversity - altitude below 1,069 $\mathrm{m}$ a.s.l., low geodiversity - altitude 1,069-1,218 m a.s.l., medium geodiversity - altitude 1,218-1,376 $\mathrm{m}$ a.s.l., high geodiversity - altitude 1,376-1,552 $\mathrm{m}$ a.s.l., very high geodiversity - altitude over 1,552 m a.s.l.

Streams: very low geodiversity - very flat slope below 5\%, low geodiversity -flat slope $5-10 \%$, medium geodiversity - medium slope $10-25 \%$, high geodiversity -steep slope $25-50 \%$, very high geodiversity - very steep slope over $50 \%$.

Waterfalls: very low geodiversity - height below $0.1 \mathrm{~m}$, altitude below 1,001 m a.s.l., low geodiversity - height $0.5-5 \mathrm{~m}$, altitude 1,001-1,065 $\mathrm{m}$ a.s.l., medium geodiversity - height 5-12 m, altitude 1,065-1,142 $\mathrm{m}$ a.s.l., high geodiversity height $12-23 \mathrm{~m}$, altitude 1,142-1,467 $\mathrm{m}$ a.s.l., very high geodiversity - height over $23 \mathrm{~m}$, altitude over $1,467 \mathrm{~m}$ a.s.l.

\section{Pedological elements:}

Soils: very low geodiversity - fluvisols, anthrosols, low geodiversity - histosols, medium geodiversity - podzols, phaeozems, high geodiversity - cambisols, very high geodiversity - regosols, leptosols.

\section{Geoecological elements:}

Geoecological belts: very low geodiversity lower montane forest zone: below 1,250 m a.s.l., low geodiversity - upper montane forest zone: 1,250-1,550 $\mathrm{m}$ a.s.l., medium geodiversity - subalpine zone: 1,550-1,800 m a.s.l., high geodiversity - alpine zone: altitude 1,800-2,300 m a.s.l., very high geodiversity - seminival zone: altitude over $2,300 \mathrm{~m}$ a.s.l.

The range of choice was limited by availability of the elements in geodatabase of the Tatra Na- tional Park. Their quantity and quality, however, seem to be sufficient to create a detailed geodiversity map of this area at this stage of study. It is worth noticing, that the above mentioned elements represent three types of object, i.e. points (springs, caves, waterfalls), lines (streams) and polygons (the remaining elements). Undoubtedly, the polygon objects suits geodiversity analysis best, assuring consistent valorization of the entire analysed area. The other two elements might seem debatable. It was assumed that line and point objects, in their scope, increase local geodiversity value. Hence, in spite of a certain degree of arbitrariness in reference to choice of objects' features, their limited spatial impact on overall geodiversity value was taken into consideration.

The above mentioned geological, geomorphological, geomorphometric, hydrographic, pedological and geoecological elements underwent map algebra operations. The map algebra procedures can be carried out by means of various methods, which use WLC (weighted linear combination) modeling. Malczewski (2000) discusses full range of these methods, and the generating commensurate attribute maps procedure was chosen. The scores for all attribute map layers were standardized by attributing to raster map grids geodiversity values from 1 (very low geodiversity) to 5 (very high geodiversity).

Linear map algebra was carried out by summing up scores of all (11) attribute map layers within the domain of every raster map grid. It can be assumed that the sum is weighted in its specific case, where all the layers were multiplied by the same digit, for example 1. Linear map algebra was performed to assess complex geodiversity of the TPN; values of all grids vary within the range from 6 to 37 (Fig. 1).

The next stage of deriving geodiversity map of Polish Tatra Mountains was reclassification procedure. Figure 2 presents the distribution of quantity of raster map grids with adequately summed up geodiversity value. It is easy to notice that the graph is positive skewed and the most TPN area is assigned to sums of geodiversity values from 13 to 20 scores. It was decided to use three methods in the process of reclassification: natural breaks (Jenks), quantiles and equal intervals (Table 1). In each of these methods different results may be achieved, but they do not change the previously 


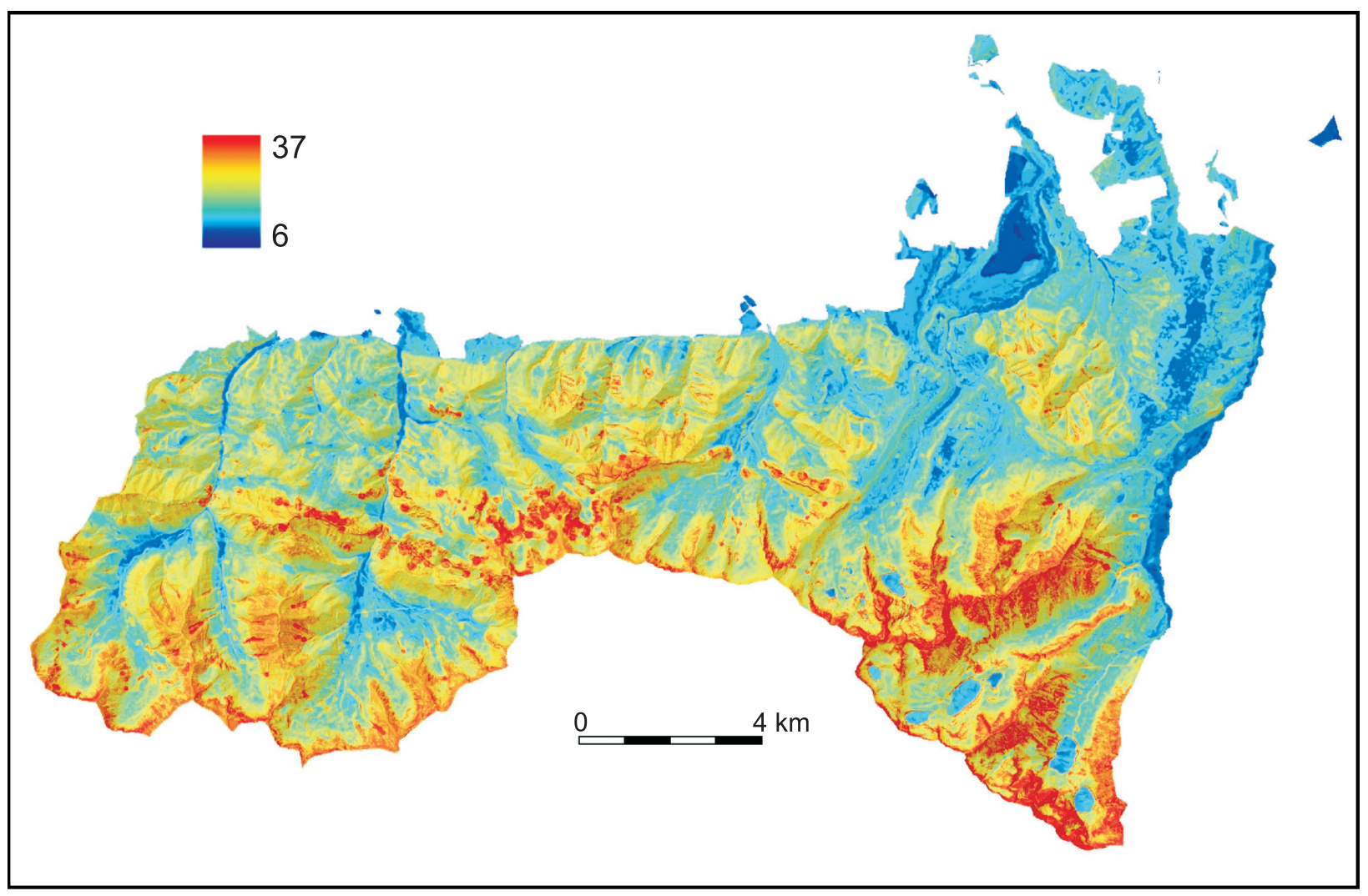

Fig. 1. Total geodiversity map of the Tatra National Park as an effect of summing scores for eleven thematic layers.

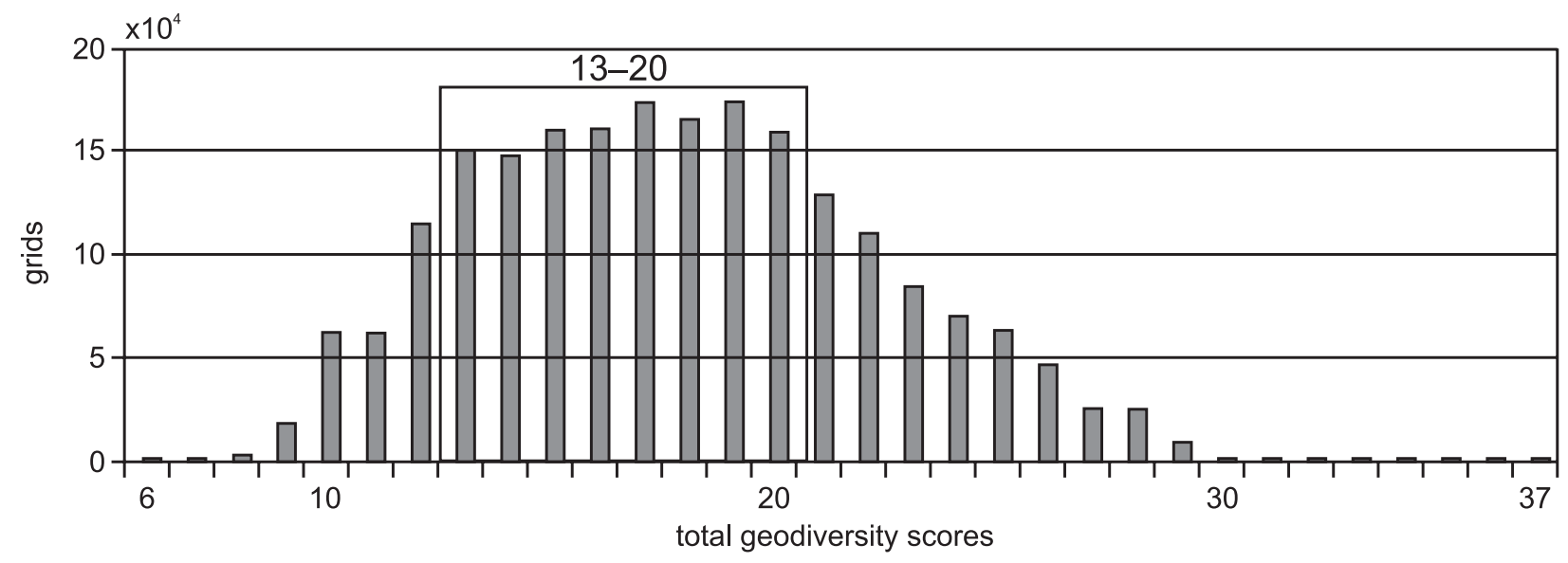

Fig. 2. Histogram of total geodiversity map grids for total geodiversity scores; scores 13-20 are explained in text.

stated opinion about the dominance of sums of geodiversity values of 13-20. The given range of scores corresponds with 2 and 3 degree of geodiversity, which all in all in subsequent methods cover: equal intervals - $84,52 \%$, quantiles $-46,89 \%$ and natural braeks (Jenks) - 53,84\%. The discrepancy between the results allows excluding equal intervals method. Natural breaks (Jenks) and quantiles show similar, satisfactory results (see
Q-NBJ relation in Table 1). Of these two methods, natural breaks (Jenks), on the basis of fieldwork, seems to be a better method to differentiate Tatra Mountains natural environment. Quantiles method gave more consistent, less contrastive results in relation to individual geodiversity degrees. That is why it was decided to use natural breaks (Jenks) to derive final map with the division into 5 geodiversity degrees (classes) (Fig. 3). 


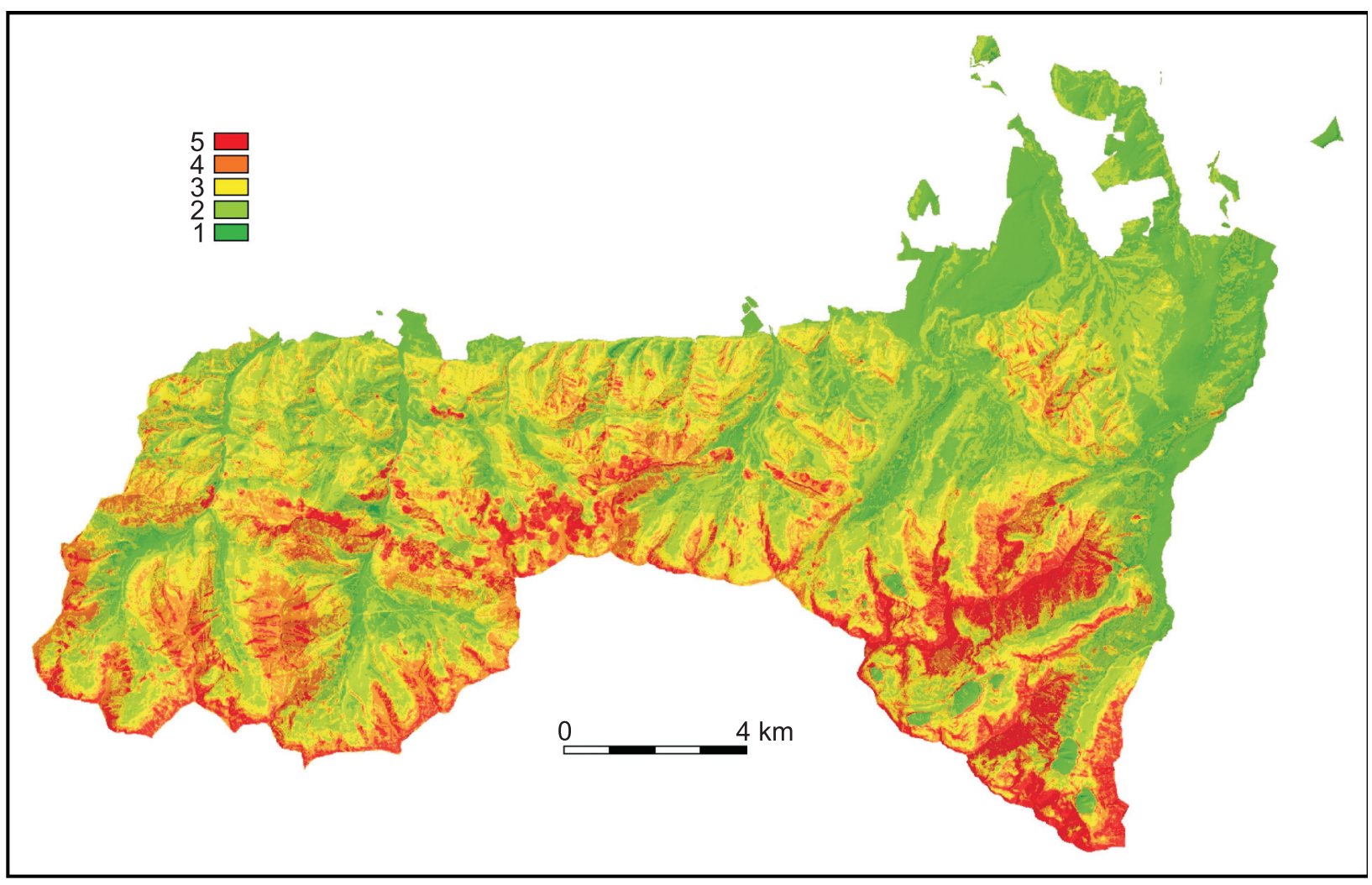

Fig. 3. Geodiversity map of the Tatra National Park after reclassification by natural breaks (Jenks) method. 1 - very low geodiversity, 2 - low geodiversity, 3 - medium geodiversity, 4 - high geodiversity, 5 - very high geodiversity.

Table 1. The distribution of variation of geodiversity degrees and their coverage of area [\%] in the Tatra National Park according to the three methods of the division into 5 geodiversity degrees.

\begin{tabular}{|c|c|c|c|c|c|c|}
\hline \multirow{2}{*}{ Method } & \multirow{2}{*}{ Parameter } & \multicolumn{5}{c|}{ Degree of geodiversity } \\
\cline { 3 - 7 } & & $\mathbf{1}$ & $\mathbf{2}$ & $\mathbf{3}$ & $\mathbf{4}$ & $\mathbf{5}$ \\
\hline \multirow{2}{*}{ Equal Intervals (EI) } & Range & $6-12.2$ & $12.2-18.4$ & $18.4-24.6$ & $24.6-30.8$ & $30.8-37.0$ \\
\cline { 2 - 8 } & Area [\%] & 3.97 & 45.79 & 38.73 & 11.41 & 0.11 \\
\hline \multirow{2}{*}{ Quantiles (Q) } & Range & $6-14$ & $14-17$ & $17-20$ & $20-23$ & $23-37$ \\
\cline { 2 - 8 } & Area [\%] & 26.37 & 23.38 & 23.51 & 15.23 & 11.51 \\
\hline \multirow{2}{*}{ Natural breaks (Jenks) (NBJ) } & Range & $6-13$ & $13-17$ & $17-20$ & $20-24$ & $24-37$ \\
\cline { 2 - 8 } & Area [\%] & 19.42 & 30.34 & 23.50 & 18.54 & 8.20 \\
\hline EI-Q relation & {$[-]$} & 22.40 & 22.41 & 15.22 & 3.82 & 11.40 \\
\hline Q-NBJ relation & {$[-]$} & 6.95 & 6.96 & 0.01 & 3.31 & 3.31 \\
\hline EI-NBJ relation & {$[-]$} & 15.45 & 15.45 & 15.23 & 7.13 & 8.09 \\
\hline
\end{tabular}

\section{Implications for geotourism}

Areas of the highest geodiversity degree, i.e. class 5, were visualised on orthophotomap of the Tatra National Park (Fig. 4) and they cover merely $8,2 \%$ of the TPN area. It is so due to geology, landform energy, slopes, landform fragmentation and geoecological belts. Most of the investigated layers categorizes ridges as more geodiversed than valley areas. There are more such areas in High Tatras than in Western Tatras.

Figure 5 presents touristic trails scheme plotted on geodiversity map. It becomes clear that the most popular touristic trails are adjacent to areas of very high geodiversity, such as the following trails: 


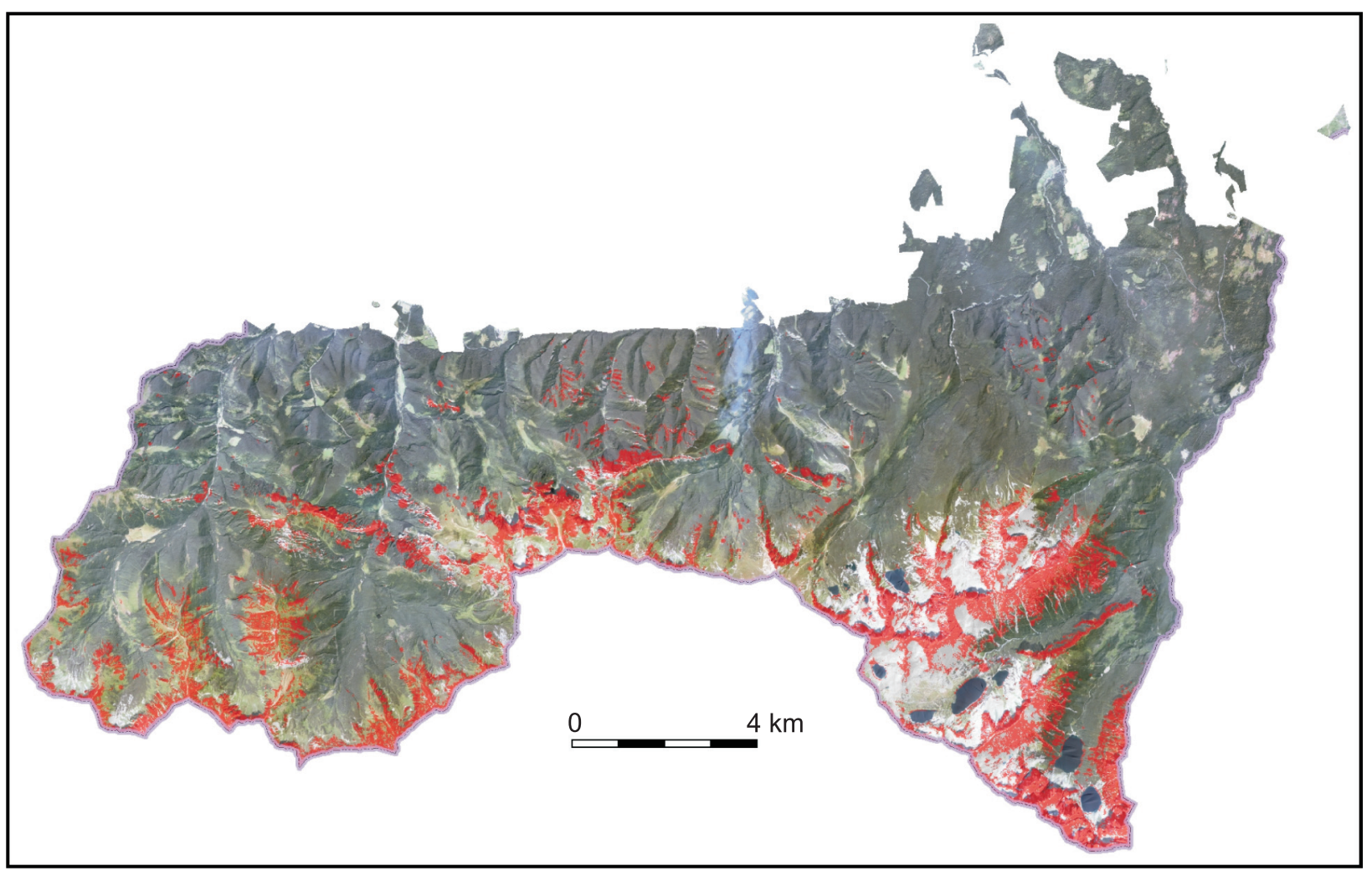

Fig. 4. The highest geodiversity degree (in red) is visualised on orthophotomap of the Tatra National Park.

- the red trail to Rysy (by Morskie Oko, Czarny Staw pod Rysami)

- the red trail to famous Orla Perć - from Krzyżne pass to Świnica

- the red trail to Przełęcz pod Chłopkiem pass In the western part of the Tatras the most attractive touristic trails close to areas of the highest geodiversity are:

- the red and the blue trail to Giewont

- the green trail down the Kościeliska Valley (in its upper parts) and the surroundings of Raptawicka Turnia.

Amongst many geotouristically interesting parts of the Tatra Mountains Dolina Pięciu Stawów (Valley of Five Ponds) appears to be the most appealing. It is marked by high quantity and high variety of post-glacial forms on valley bottom as well as on its slopes. That is why on a relatively small area (merely $6,5 \mathrm{~km}^{2}$ ), there is abundance of environmental and cultural values. It is undoubtedly one of the most geotouristically attractive valley in the Tatra Mountains, what is confirmed also by Mrowczyk et al. (2010).

The trails situated down the valleys usually go by areas of low geodiversity, however, from touristic point of view, it should be noted that slopes and ridges circumvolving the valley can be marked by high geodiversity. The slopes and ridges are within tourist's sight, what raises trail's geotouristic attractiveness, for example the green trail down the Roztoka Valley. Mountain hostels, situated high in the mountains, are also very attractive as far as geodiversity is concerned: the

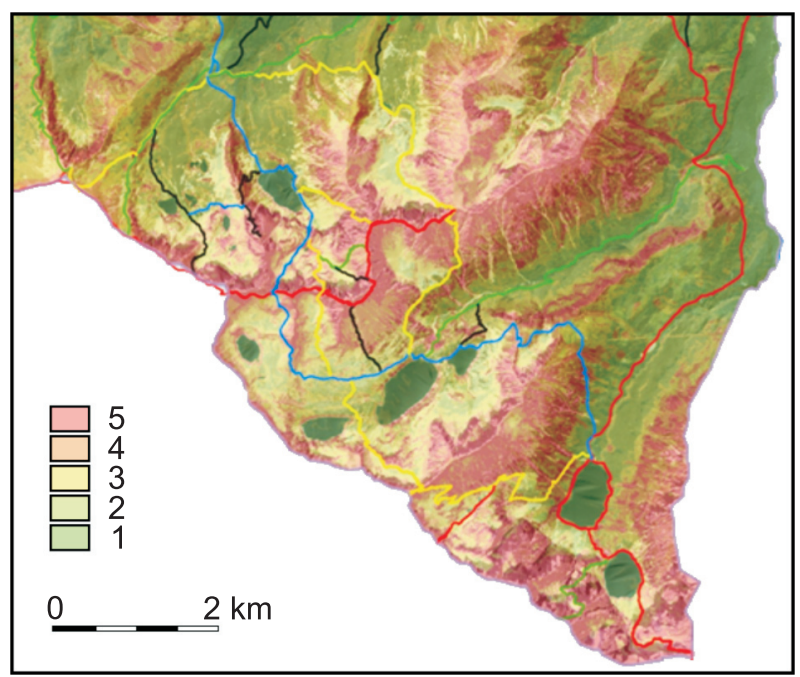

Fig. 5. Touristic trails scheme (in black, blue, green, red and yellow) on geodiversity map of High Tatras.

1 - very low geodiversity, 2 - low geodiversity, 3 - medium geodiversity, 4 - high geodiversity, 5 - very high geodiversity. 
mountain hostel in Dolina Pięciu Stawów, which is situated highest in the Tatra Mountains $(1,671$ $m$ a.s.l.) and the mountain hostel by Morskie Oko Lake (1,410 $\mathrm{m}$ a.s.l.).

Geodiversity assessment and its 5 classes should be considered individually within the limits of a given area depending on spatial scale of the study. On a background of Poland's geodiversity map almost the whole area of the TPN was assigned the highest geodiversity degree (Zwoliński 2008). The geodiversity map of the TPN presented in this paper provide more diverse results due to two reasons: a) a larger quantity of elements taken into consideration for geodiversity analysis purposes and $b$ ) data of better quality which was displayed in their higher resolution.

\section{Acknowledgments}

There was spatial and nonspatial data from the Tatra National Park geographical information system used in this paper. The authors wish to thank dr P. Skawiński and dr M. Guzik who made the data available to them. This paper was financed by Adam Mickiewicz University of Poznań, Poland. The authors would like to thank anonymous reviewers for remarks on the previous version of this paper.

\section{References}

Asrat A., Demissie M. \& Mogessie A., 2008. Geotourism in Ethiopia. Shama Books, Addis Ababa.

CASTALDINI D., 2012. Maps and multimedia tool for the popularization and promotion of protected areas of the Apennines of Modena (northern Italy). In: C.Giusti (ed.), Géomorphosites 2009: imagerie, inventaire, mise en valeur et vulgarisation du patrimoine géomorphologique. Paris: 60-65.

Cayla N., Hoblea F. \& Gasquet D., 2012. Place de la géomorphologie dans l'offre géotouristique de l'arc alpin: du réel au virtuel. In: C.Giusti (ed.), Géomorphosites 2009: imagerie, inventaire, mise en valeur et vulgarisation du patrimoine géomorphologique. Paris: 65-71.

Chybionz R. \& Tyc A., 2011. Georóżnorodność rzeźby w województwie śląskim. In: M.Mazurek, M.Ewertowski (red.), 2011. Georóżnorodność rzeźby Polski, Poznań: 30.

GeoPortal Tatry, 2012. WMS. Online: http://www.geoportaltatry.pl/, 10.1.2012.

Gray M., 2004. Geodiversity: Valuing and Conserving Abiotic Nature. Wiley, Chichester.
GRAY M., 2008. Geodiversity: the origin and evolution of a paradigm. In: C.V.Burek \& C.D.Prosser (eds), The History of Geoconservation. Geological Society, London, Special Publication, 300: 37-70. DOI: 10.1144/SP300.4

Hose T.A., 2008. Towards a history of geotourism: definitions, antecedents and the future. In: C.V.Burek \& C.D.Prosser (eds), The History of Geoconservation. Geological Society, London, Special Publication, 300: 31-36. DOI: $10.1144 /$ SP300.5.

JAČKOVÁ K., ROMPORTL D., 2008. The Relationship between Geodiversity and Habitat Richness in Šumava National Park and Krrivoklátsko Pla (Czech Republic): A Quantitative Analysis Approach. Journal of Landscape Ecology, 1(1).

Joyce E.B., 2010. Australia's Geoheritage: History of Study, A New Inventory of Geosites and Applications to Geotourism and Geoparks. Geoheritage, 2(1-2): 39-56.

Kostrzewski A., 1998. Georóżnorodność rzeźby jako przedmiot badań geomorfologii. In: K. Pękala (ed.), Główne kierunki badań geomorfologicznych w Polsce stan aktualny i perspektywy, IV Zjazd Geomorfologów Polskich, UMCS, Lublin, p. 11-16.

KostrZeWSKI A., 2011. The role of relief geodiversty in geomorphology. Geographia Polonica, 84(Sp. Iss. Pt 2): 69-74.

Kот R., 2006. Georóżnorodność - problem jej oceny i zastosowania $\mathrm{w}$ ochronie i kształtowaniu środowiska na przykładzie fordońskiego odcinka dolnej Wisły i jej otoczenia. Studia Societatis Scientiarum Torunensis, Sectio C (Geographia et Geologia), 11(2): 1-190.

Кот R., 2009, Próba ujednolicenia rangi jednostek rzeźby terenu dla delimitacji geokompleksów wybranych krajobrazów nizinnych. Problemy ekologii krajobrazu, 23: 167-179.

KOT R., LEŚNIAK K., 2006. Ocena georóżnorodności za pomoca miar krajobrazowych - podstawowe trudności metodyczne. Przegląd Geograficzny, 78(1): 25-45.

Кот R., SzмidT K., 2010. Ocena georóżnorodności rzeźby terenu fragmentu Basenu Świeckiego w skalach 1:10 000 oraz 1:25 000. Problemy Ekologii Krajobrazu, 27: 189196.

MalczewsKi J., 2000. On the Use of Weighted Linear Combination Method in GIS: Common and Best Practice Approaches. Transactions in GIS, 4(1): 5-22.

MizGAJSKI A., 2001. Odniesienie georóżnorodności do wybranych pojęć w naukach o środowisku. In: Funkcjonowanie geoekosystemów w zróżnicowanych warunkach morfoklimatycznych. Monitoring, ochrona, edukacja, A.Karczewski \& Z.Zwoliński, Bogucki Wydawnictwo Naukowe, Poznań: 369-375.

MrowczyK P., Madeja G., Doktor M., 2010. Zagospodarowanie obiektów geoturystycznych na terenie parku narodowego na przykładzie Doliny Pięciu Stawów Polskich. Problemy Ekologii Krajobrazu, 27: 473-476.

Reynard E., Erhartic B., Kozina K., Martin S., Regolini G., RoVERE A., Theler D. \& VACCHI M., 2012. Mapping the geomorphological heritage for geotourist purposes: the case of Derborence Lake area (Switzerland). In: C.Giusti (ed.), Géomorphosites 2009: imagerie, inventaire, mise en valeur et vulgarisation du patrimoine géomorphologique. Paris: 281-282.

Rodrigues M.-L. \& FonseCA A., 2012. From geomorphological Survey and mapping to Geoheritage and geotouristic maps. Application in a Karst area - The Fórnia (EML, Portugal). In: C.Giusti (ed.), Géomorphosites 2009: im- 
agerie, inventaire, mise en valeur et vulgarisation du patrimoine géomorphologique. Paris: 282-283.

SAPP M., GAIDO M.F. \& MIRÓ R.C., 2009. A Geodiversity Map: Geological-Tourist Map Of Calamuchita's Valley, Cordoba, Argentina. Proc. 24th Int. Cartogr. Conf., Santiago de Chile. p. 5.

Serrano E., Ruiz-Flaño P., 2007. Geodiversity: a theoretical and applied concept. Geographica Helvetica, 62: 140147.

Serrano E., Ruiz-Flaño P., Arroyo P., 2009. Geodiversity assessment in a rural landscape: Tiermes-Caracena area (Soria, Spain). Mem. Descr. Carta Geol. d'It., 87: 173-180.

TPN [Tatra National Park], 2012. Tatrzański Park Narodowy. Online: http://tpn.pl/, 10.1.2012.

ZwoLIŃSKI Zв., 2004a. Geodiversity. In: A.S.Goudie (ed.), Encyclopedia of Geomorphology, Vol. 1, Routledge, 417418.

ZwoLIŃsKi Zв., 2004b. Koncepcja mapy geoturystycznej (Conception of geotouristic map). In: L.Kozacki \& B.Medyńska-
Gulij, (eds.), Kartografia tematyczna w kształtowaniu środowiska geograficznego. Bogucki Wyd. Nauk., Poznań: 293-301.

ZwoLIŃSKI Zв., 2007. Methodology for determining landform geodiversity in Poland, IAG/AIG Regional Conference on Geomorphology, Kota Kinabalu, Malaysia, 25-29 June 2007, 30.

ZwoLIŃSKI Zв., 2008. Designing a map of the geodiversity of landforms in Poland. IAG and AIGEO International Meeting "Environmental Analysis and Geomorphological Mapping for a Sustainable Development", Addis Ababa, Ethiopia, February 26, 2008. Abstract Book, p. 18-22.

Zwolíśs Zв., 2009. The routine of landform geodiversity map design for the Polish Carpathian Mts. In: E.Rojan \& A.Łajczak (Eds.), Geoecology of the Euroasiatic Alpids. Landform Analysis, 11: 79-87.

ZwOLIŃSKI Zв., 2010. Aspekty turystyczne georóżnorodności rzeźby Karpat. Prace Komisji Krajobrazu Kulturowego PTG, 14: 316-327. 